\title{
Alpha-Galactosylceramide-Pulsed Autologous Dendritic Cells
}

National Cancer Institute

\section{Source}

National Cancer Institute. Alpha-Galactosylceramide-Pulsed Autologous Dendritic Cells. NCI Thesaurus. Code C78489.

A cancer vaccine comprised of autologous dendritic cells (DCs) pulsed with the marine sponge glycolipid alpha-galactosylceramide (alpha-GalCer) with potential immunostimulatory and antimetastatic activities. Upon administration, alphagalactosylceramide-pulsed autologous dendritic cells may result in the activation and proliferation of a subset of endogenous natural killer T (NKT) cells, B cells, and CD4+ and CD8+ T cells, and the production of interferon-gamma and interleukin-12; these cascade events may result in a T helper-1 cell-biased proinflammatory antitumor immune response. The NKT cell ligand alpha-GalCer was originally isolated from the marine sponge Agelas mauritianusis. 